\title{
TRAINING NEEDS OF BROILER BREEDERS IN FIELDS OF (MANAGEMENT, AND MARKETING) IN DUHOK GOVERNORATE AND ITS RELATION WITH SOME VARIABLES
}

\author{
Ismail. A. TAHA and ABID Ali HaSAn AL-DOSKi \\ Dept. of Agricultural Extension And Rural Development, College of Agricultural Engineering \\ Sciences, University of Duhok, Kurdistan Region-Iraq
}

(Accepted for Publication: October 21, 2019)

\begin{abstract}
The main objective of the study was to assess the training needs of broiler breeders in Duhok governorate, and to find the relationship between selected characteristics and training needs. The research sample included 153 breeders representing $76.5 \%$ of the research population. Data used for the study were obtained using structured questionnaire and personal interviews. SPSS software were used to analyze the data collected, statistics such as frequency, percentage, mean, standard deviation, correlation were used. The result shows that $43.1 \%$ of the respondents need extensive training in all the studied areas (marketing and management) and there is a significant correlation between the need for training and the independent variable (ownership) and no significant relationship between training needs and each of (age, Educational level, Number of years of experience in broiler breeding, and participation in training). In the light of the study findings, it was recommended that Agricultural extension in Duhok governorate should organize regular training for broiler breeders in the studied areas.
\end{abstract}

KEYWORDS: Training needs, broiler breeders, Duhok. https://doi.org/10.26682/cajuod.2020.22.2.10

\section{INTRODUCTION}

$\mathbf{T}$ The agricultural development has an important role in economic and social development in most developing countries due to the role played by the agricultural sector in supporting and enhancing the national economy of these countries in facing the demand for agricultural or food agricultural commodities (Al-Nabhan, 2004). Animal production is an important part of agriculture, and aims at producing useful products and services of value to humanity. In view of their multi-functional role, animals are often reared together with crops in farming systems for ecological, economic, social and cultural reasons that directly benefit farmers, the poor and their livelihoods. Together with other natural resources such as land, crops and water, animal production is also concerned with issues of sustainability and protection of the environment. Agricultural sustainability not only involves environmental aspects, but includes political and socio-economic aspects (Devendra 2007b).

Poultry production, as one important segment of livestock product, has a peculiar privilege to contribute to the sector. This is mainly due to small size and their fast reproduction compared to most other livestock and its well fitness with the concept of small-scale agricultural development. Moreover, it goes high ecofriendly and does not compete for the other scarce land resources (Muhiye 2007). The poultry industry was undergoing on both technological and scientific advances to meet its more commercialization growth rate. Chicken are now products of intense rapid and efficient growth and high rate of production due to genetic selection (Renema \& Robinson, 2004).

The acceptance of farmers in developed countries for many modern agricultural techniques and their continued application have radically changed agricultural productivity and knowledge levels of the rural population. Agricultural extension is an essential component of any agricultural system and plays a major role in achieving agricultural development through the transfer of appropriate technologies and the development of agricultural production methods in different fields (Rivera 2003). Agricultural 
extension is therefore aimed at acquiring and disseminating new knowledge and techniques among producers and providing them with the necessary skills to apply them (Hassan 2005). The management of broiler flocks is influenced by several factors, primarily the knowledge of the breeders and their skills in the development of the poultry production (Ibrahim 1983). It is very important that broiler breeders are well versed in the relevant scientific recommendations in order to become scientifically qualified to apply them properly.

Agricultural extension had a crucial role in identifying the problems facing farmers and transferred to scientific research to study, also find appropriate solutions, recommendations. The needs assessment and training for broiler breeder's is the base for extension process and its activities so, determining these needs in different practices of broiler farming such as management practices and marketing considers an important step in planning the appropriate interventions that aiming at building breeders capacity and consequently achieving the development objectives. Therefore this study is conducted to answer the following questions: what are the training needs of broiler breeders in Duhok governorate? What are the factors affecting the training needs of breeders and what are the problems and obstacles of breeders in management and marketing?

\section{OBJECTIVES OF THE RESEARCH}

The overall objective of the research is to identify the extension training needs of broiler breeders in the fields of (management and marketing) in overall Duhok Governorate, the specific objectives are:

1 - To determine the level of training needs of broiler breeders in the fields of (management, marketing) in general.

2- To determining the relationship between the training needs of the broiler breeders in the fields of (management, marketing) in Duhok Governorates and the following independent variables: (age - educational level - number of years of work experience - Type of farm ownership - participation in training courses)

3- To identify the problems and obstacles facing the broiler breeders in the fields of (management, marketing) of Duhok governorate.

\section{HYPOTHESIS}

There is no significant correlation between the training needs of broiler breeders in Duhok governorate as dependent variable and each of the following independent variables: age educational level - number of years of work experience - Type of ownership of the broiler farms - participation in training courses. The hypothesis was tested in null hypothesis

\section{MATERIALS AND METHODS METHODOLOGY POPULATION AND SAMPLE}

The research population is composed of all the 200 breeders in the Duhok Governorate the data was collected from 153 breeders representing about $76.5 \%$ of the research population, face and content validity of the instrument was established by the panel of experts, their suggestion were incorporated in the final version of the instrument.

\section{RESEARCH DESIGN AND DATA \\ ANALYSIS}

To analyze the objectives of the study a questionnaire of three parts was designed as follow: the first includes a set of questions to recognize personal and functional characteristics of breeders. The second includes a scale to measure the dependent variable, consist of 30 items distributed among 2 domains (management and marketing). The third includes a set of questions to determine the main problems and obstacles of the broiler production perceived by the targeted of broiler breeders.

\section{RESULT AND DISCUSSION \\ 1- Determining the level of training needs of broiler breeders in the fields of (management and marketing) in general. \\ Broiler breeders were divided into three} groups according to the degree of training need in the studied domains. First group included the respondents whose degree of training needs ranged between (105 and 181), (10.46\%) of the total respondents. Second group included the respondents whose degree of training need ranged between (182and 258), (46.40\%). Third group included the respondents whose degree of training needs ranged between (259and 335), $(43.14 \%)$. The mean of training needs for management and marketing 248.54 with a standard deviation of 51.138. The findings 
indicate that overall training needs of breeders in Duhok governorate $(89.54 \%)$ in descending order from moderate to high .May be the reason behind this is that the majority of the broiler breeders in Duhok governorate (55\%) belong to low experience group (table 3). Thus proper extension training programs are needed for the broiler breeders to improve their skills in management and marketing areas.

Table (1): Distribution of respondents according to their training needs

\begin{tabular}{|c|c|c|c|c|c|}
\hline No & groups & frequency & Present $\%$ & mean & SD \\
\hline 1 & $(105-181)$ & 16 & 10.46 & \multirow[t]{4}{*}{248.54} & \multirow[t]{4}{*}{51.138} \\
\hline 2 & $(182-258)$ & 71 & 46.40 & & \\
\hline 3 & $(259-335)$ & 66 & 43.14 & & \\
\hline & Total & 153 & 100 & & \\
\hline
\end{tabular}

The table (2) showed that extension training programme of broiler breeders in the field of management is in the forefront of the studied areas in terms of training needs with an arithmetic mean of 64.65. This is because broiler breeders require good knowledge and skills in management activities to run their enterprises profitably and upgrading their management skills will enable them to cope with the rapid changes in agribusiness environment and run their projects more efficiently and profitably.

The need for training in marketing came in the second rank with a mean of 42.28 . This is because markets play a crucial role in the adoption of new technologies and market access is one of the factors that can transform small holder's agriculture in developing countries towards

Table (2): Show rank order of training needs for both fields

\begin{tabular}{cccc}
\hline No & Fields & Mean & Ranking \\
\hline 1 & Management & 64.65 & 1 \\
\hline 2 & Marketing & 42.28 & 2 \\
\hline
\end{tabular}

2- Determining the relationship between the training needs of the broiler breeders in the fields of (management, marketing) in Duhok Governorates and the following independent variables: (age - educational level - number of years of work experience - Type of ownership of the broiler farms - Participation in training)

\section{1-Age}

Table 3 show the respondents according to their age was divided in to three categories as follows, lower age $=26$ year, higher age $=61$ year, the mean age of the respondents was 42.84 with a standard deviation of 8.914. Approximately half of respondents are $(47 \%)$ of the poultry breeders were between (38 - 49) years of age. $26 \%$ of them belong to (26-37) year's categories and also $26 \%$ of them to (50-61) categories. To find the correlation between the age and respondents training needs degree, the simple correlation coefficient was used ( $\mathrm{r}=0.036)$, which is not significant. This mean there is no correlation between the two variables, which implies that the null hypothesis had been proven true. May be the reason that all broilers breeders need trainings in the fields of Management and marketing irrespective of their age. This result agrees with studies of Kareem (2013) and AlBarwary (2013).

\section{2- Educational level}

In the case of education, a large majority $25.49 \%$ of the respondents were Read and Writing, followed by 18.3 and $17.0 \%$ of the respondents that attained primary and College, respectively (Table 3 ). While only $(8.5 \%)$ of respondents were illiterate. To find correlation between the educational level variable and respondents training needs degree, the spermanrank correlation coefficient was used $(\mathrm{r}=-0.108)$, which is insignificant. This mean there is no correlation between two variables, which implies that the null hypothesis had been proven true. Perhaps because all the respondents need training regardless of their educational level. 
This result agrees with studies of Al-Talib (2007) and Ali (2013).

\section{3- Experience}

The distribution of broiler breeders according to number of years of working in this field ranged between 1-24 years .The results of the study revealed that $54 \%$ had been in poultry farming business for $1-8$ years, $36 \%$ had between 9-16 years' experience while $8.5 \%$ had between 17-24 years. The mean of experience years was 8.78 with standard deviation of 5.327. To find the correlation between the experience and respondents training needs degree, the simple correlation coefficient was used ( $\mathrm{r}=-$ 0.090), which is not significant. This mean there is no correlation between the two variables, which implies that the null hypothesis had been proven true. May be the reason is that the majority of broiler breeders are belong to low experience, therefore training in the both domain is required. This result agrees with studies of Al-Juborri and Al-Abassi (2003) and Al- Doski and Al-Sinahy (2015).

\section{4-Ownership}

The majority of the broiler breeders belong to farm ownership category (50\%). (29\%), $11.76 \%, 8.5 \%$ are belonging to rent, Contract and share respectively. This implies that the largest of proportion of the respondents have property of farms ownership. To find correlation between the ownership variable and respondents training needs degree, the spearman-rank correlation was used $\left(\mathrm{r}=0.193^{*}\right)$, which is significant value at the probability level 0.05 . This means that there is significant correlation between the two variables and reject the null hypothesis in favor of the alternative hypothesis. May be the reason is that the farm ownership has an economic power and status attributed especially when it is legally owned. This result agrees with study of Al-Jubourri (2000).

\section{5-Participant in training}

As seen from table (3) that the respondents who participated in training are $(9.8 \%)$ and the respondents who did not participate on training $(90.2 \%)$. it means that the majority of respondents did not participate in any training, which is reflect clear deficiency in the number of training provided for broiler breeders on Duhok governorate. To find correlation between the participation on training variable and respondents training needs degree, the spearman-rank correlation was used $(\mathrm{r}=-0.111)$, which is insignificant. This mean there is no correlation between two variables, which implies that the null hypothesis had been proven true. Because most of the broiler breeders did not participate in trainings although they are necessary for broiler breeders to enhance their work competence and skills. This result agrees with study of Al-Abassi et al (2009).

Table (3): Distribution of respondents according independent variables

\begin{tabular}{|c|c|c|c|c|c|}
\hline Variables & frequency & Present\% & Mean & S.d & $r$ \\
\hline \multicolumn{6}{|l|}{ 1.Age } \\
\hline$(26-37)$ & 40 & 26.14 & \multirow{4}{*}{42.84} & \multirow{4}{*}{8.914} & \multirow{4}{*}{0.036} \\
\hline$(38-49)$ & 73 & 47.72 & & & \\
\hline$(50-61)$ & 40 & 26.14 & & & \\
\hline Total & 153 & 100 & & & \\
\hline \multicolumn{6}{|l|}{ 2.Educational level } \\
\hline Illiterate & 13 & 8.5 & & & \multirow{8}{*}{-0.108} \\
\hline Read and Writing & 39 & 25.49 & & & \\
\hline Primary & 28 & 18.3 & & & \\
\hline Secondary & 16 & 10.46 & & & \\
\hline High school & 17 & 11.11 & & & \\
\hline Institute & 14 & 9.15 & & & \\
\hline College & 26 & 17.0 & & & \\
\hline Total & 153 & 100 & & & \\
\hline
\end{tabular}




\begin{tabular}{|c|c|c|c|c|c|}
\hline Variables & frequency & Present\% & Mean & S.d & $r$ \\
\hline \multicolumn{6}{|l|}{ 3.Experience } \\
\hline \multicolumn{6}{|l|}{ Number of years } \\
\hline$(1-8)$ & 84 & 54.9 & \multirow{4}{*}{8.78} & \multirow{4}{*}{5.327} & \multirow{4}{*}{-0.090} \\
\hline$(9-16)$ & 56 & 36.6 & & & \\
\hline$(17-24)$ & 13 & 8.5 & & & \\
\hline Total & 153 & 100 & & & \\
\hline \multicolumn{6}{|l|}{ 4.Ownership } \\
\hline Classes & & & & & \multirow{6}{*}{ *0.193 } \\
\hline Owner & 77 & 50.33 & & & \\
\hline Contract & 18 & 11.76 & & & \\
\hline Rent & 45 & 29.41 & & & \\
\hline Share & 13 & 8.5 & & & \\
\hline Total & 153 & 100 & & & \\
\hline \multicolumn{6}{|c|}{ 5.Participation on training } \\
\hline Classes & & & & & \multirow{4}{*}{0.111} \\
\hline Participant & 15 & 9.8 & & & \\
\hline Non participant & 138 & 90.2 & & & \\
\hline Total & 153 & 100 & & & \\
\hline
\end{tabular}

\section{3-Identifying problems and obstacles facing the broiler breeders in the governorate of Duhok}

Table (4): Shows average scores of problems extents

\begin{tabular}{|c|c|c|c|}
\hline No & Paragraphs & Mean & Ranking \\
\hline 2 & Imported frozen chicken meat & 4.836 & 1 \\
\hline 1 & Lack of government cooperation with broiler breeders & 4.803 & 2 \\
\hline 12 & Authorities responsible for controlling and watching the broiler farms is rare & 4.254 & 3 \\
\hline 4 & High feed prices & 4.150 & 4 \\
\hline 3 & Lack of reliable sources of information on poultry farming & 4.039 & 5 \\
\hline 11 & $\begin{array}{l}\text { Lack of coordination between the Faculty of Agriculture and Veterinary and breeding } \\
\text { farm (broiler breeders) }\end{array}$ & 4.019 & 6 \\
\hline 6 & The extra duration of fattening according to normal length & 3.856 & 7 \\
\hline 10 & Lack of private advisors offices in raising broilers & 3.627 & 8 \\
\hline 7 & High percentage of losses & 3.529 & 9 \\
\hline 9 & High production costs of chicks & 3.333 & 10 \\
\hline 8 & Difficulty getting chicks & 2.895 & 11 \\
\hline 5 & Difficulty obtaining feed & 2.849 & 12 \\
\hline
\end{tabular}

The table (4) shows respondents opinions on the various problems that faced by broilers breeders in farm managements and marketing in Duhok governorate. The results reveal that the three greatest factors that affect broilers breeders abilities in farm management and marketing production in Duhok governorate are (Imported frozen chicken meat, Lack of government cooperation with broiler breeders, Authorities responsible for controlling and watching the broiler farms is rare). May the lack of government support and unavailability of storage facilities in the targeted area are behind that. Therefore government should pay attention to develop breeding farms by providing postharvest facilities and feed with good and cheap nutritional formula to overcome these obstacles. 


\section{CONCLUSIONS}

1-The broiler breeders in Duhok governorate are in great need for training in the both domain studied (management and marketing).

2-The breeders' needs for training in the management domain came first under study, and the need for training in marketing came second. 3-There is a significant correlation between (type of farm ownership) and need for training. 4- The three greatest factors that affects broilers breeders abilities in farm management and marketing production in Duhok governorate (Imported frozen chicken meat, Lack of government cooperation with broiler breeders, Authorities responsible for controlling and watching the broiler farms is rare).

\section{RECOMMENDATION}

1- Proper extension training programs should be arranged by agricultural extension agency for the broiler breeders to improve their skills in management and marketing areas.

2 - It is necessary non-government and other institutions and the public make further efforts the animal production that affects broiler production.

3-There is an urgent needs to organize and carry out intensive information campaigns to educate consumer about the importance of the local production for health. This can be done by instructing them through mass media, stickers, labels, posters and other available extension means.

4- It is felt necessary that special emphasis should be given by the Universities and research stations to fix research priorities and direct their scientists towards technological need based research in areas of broiler management and marketing.

\section{REFERENCES}

Al- Talib, Ahmed A. (2007). Assessment of knowledge level of tomato growers and its relationship with some variables in Zomar district/ Nenava governorate, Agric. Educe. Dept. College of Agri. \& Forestry / Univ. of Mosul / Iraq. Al- Rafidain Journal, 35:4.

Al-Abassi, Aamel, F., Hassan, Aabid, A., Fathi, Arwa, M., and Edress, Luma, M., (2009). Needs of Agricultural Extension Workers in Kirkuk \& ASulaimani Provinces For Some
Agricultural Extension Knowledge \& Competencies. Tikrit Journal for Agriculture Science.9:2

Al-Barwary (2013). Training needs of greenhouse farmers in the province of Duhok and their relationship with some factors. College of Agriculture. University of Salahaddin-Erbil. (Diploma. Thesis)

Al-Doski, Abid. A. and Alsinayi, Mijda. B. (2015). Forest and rangeland staff training needs in Iraqi Kurdistan Region and correlation to personal and occupational factors. Alexandria Science Exchange Journal. 36:3.

Ali, M. jawhar. (2013). Training Needs of Fish Farmers in the Province of Erbil and its Relationship with some Variables. Agriculture College - University of Salahaddin - Erbil , (Diploma. Thesis).

Al-Jubourri, Ali. A., and Al-Abassi, Aamil. F. (2003): Training needs of vegetable farmers in Sherqat district Salaheddin province and their relation with some variables. Iraqi journal of agriculture science. 4:1.

Al-Jubourri, Ali, A. (2000). Training needs of vegetable farmers in Sherqat district and their relation with some variables. College of Agriculture \& Forestry. University of Mosul. ( M. Sc. Thesis).

Al-Nabhan, M. (2004). Principles of Measurement in Behavioral Sciences, First Edition, Dar AlShorouk for Publishing and Distribution, Amman, Jordan.

Devendra, C. (2007b). Perspective on animal production systems in Asia. Livest. Sci., 106: 1-18. [A useful detailed discussion on the different animal production systems, links between them, opportunities for NRM and the future scenario in Asia].

Hassan, M. R. (2005). Role of Agricultural Extension in Rural Development, Iraqi Agriculture Journal. 1:63.

Ibrahim, M. I. (1983). Scientific Foundations in the Care and Production of Poultry, Faculty of Agriculture and Forestry, Mosul University.

Kareem, S. Abdulla. (2013). Training Needs of Cucumber Crop Farmers in Greenhouses in Erbil Province. College of Agricuture. 
University of Salahaddin-Erbil. (Diploma. Thesis)

Muhiye, M. G. (2007). Characterization of smallholder poultry production and marketing system of Dale,Wonsho and Loka Abaya Weredas of Southern Ethiopia thesis. University of Hawassa, Ethiopia.
Renema, R. A., \& Robinson, F. E. (2004). Defining normal: Comparison of feed restriction and full feeding of female broiler breeders. World's Poultry Science Journal Vol. 60, 508-522.

Rivera, W. M. (2003). Agricultural Extension, Rural development and the food security challenge. Food and Agriculture Organization of the United

Nations

Rome.

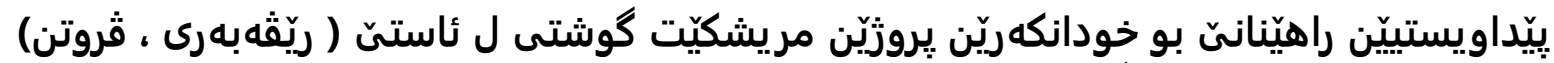

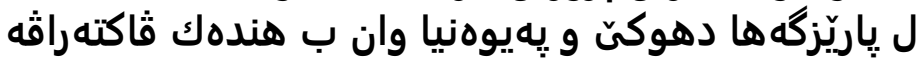

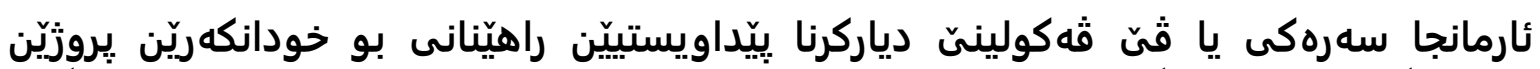

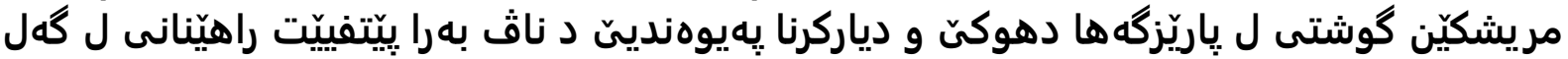

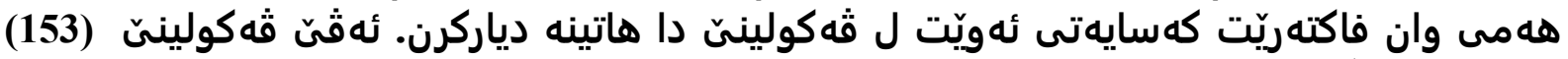

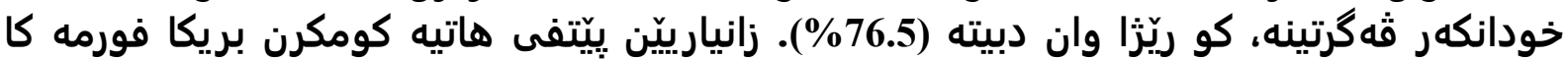

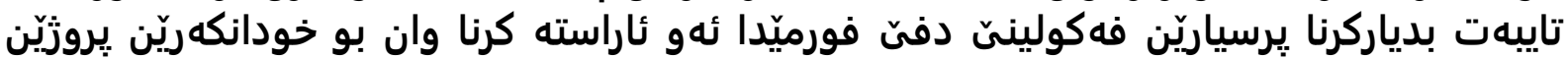

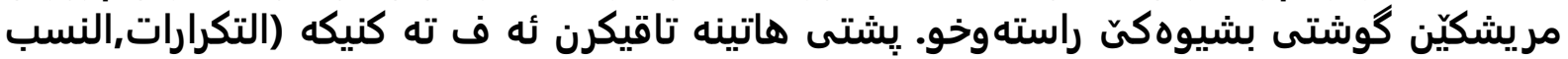

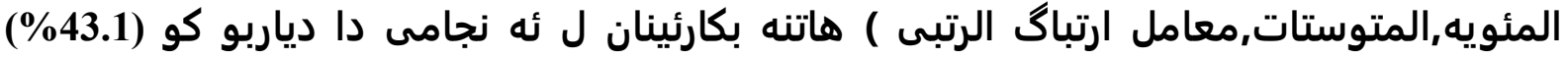

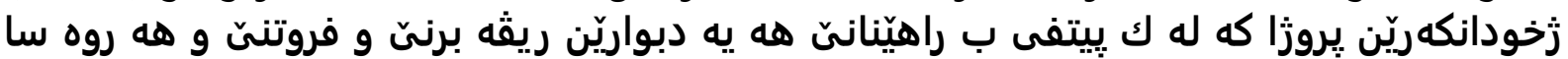

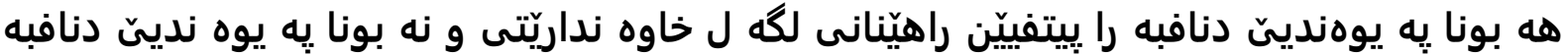

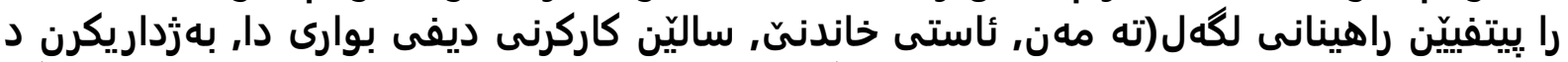

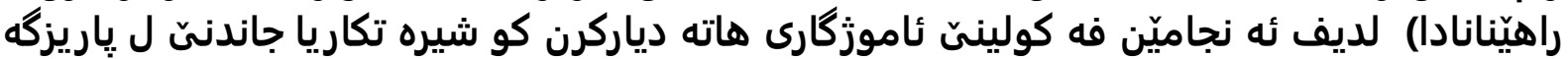

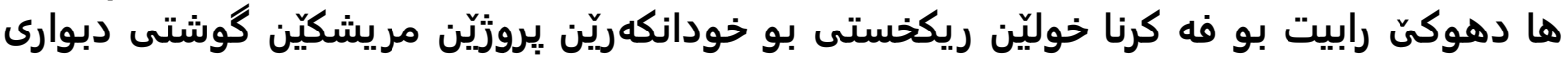
(ريقه برن,فروتن).

الاحتياجات التدريبية لمربي فروج الحم في مجال (الادارة والتسويق) في محافظة دهوك وعلاقتها ببعض مض العوامل. 
الخلاصة

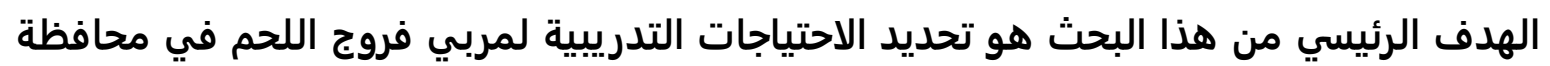

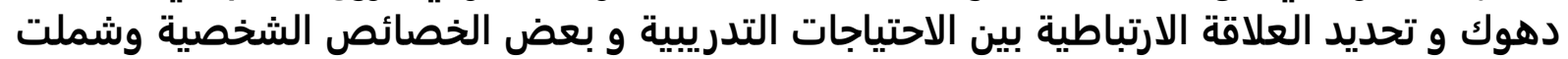

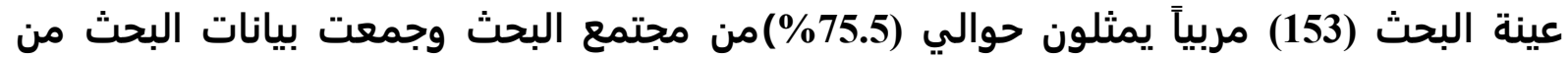

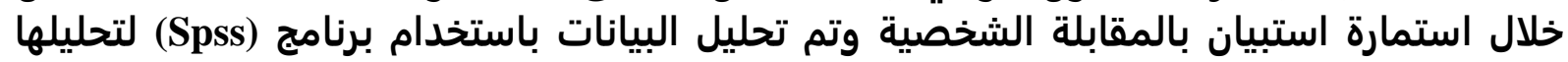

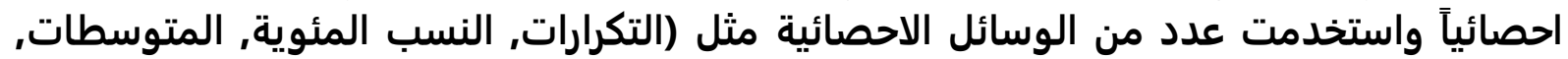

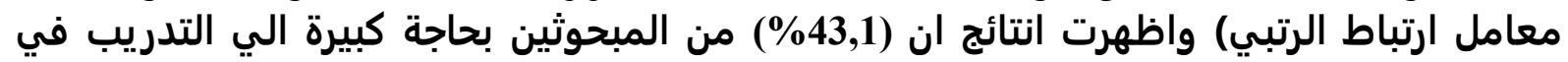

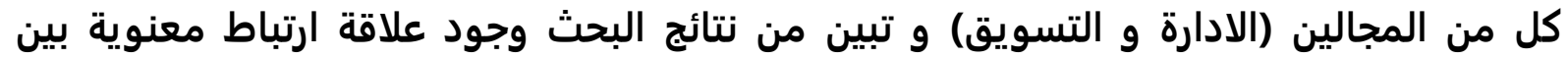

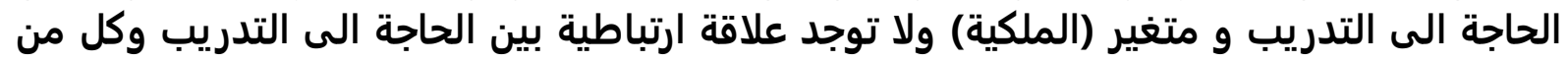

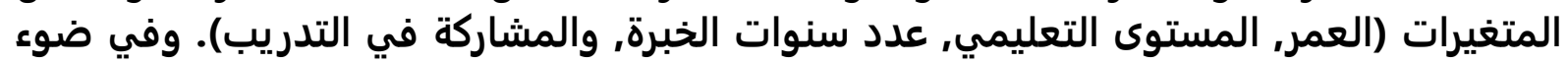

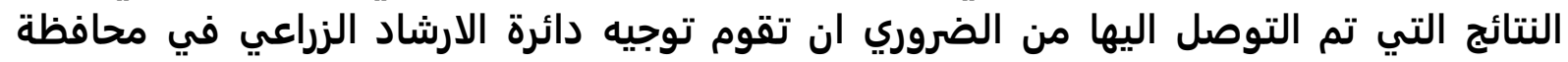
دهوك بفتح دورات تدريبية منتظمة لاصحاب فروج اللحم في المجالين (التسويق والادارة). 